\title{
Szczęście nie jest częścią przyjemności
}

\author{
Alain BROSSAT ${ }^{1}$
}

KEYWORDS

happiness; level of happiness; friendship; pleasure; Michel Foucault

ACKNOWLEDGEMENT / ŹRÓDłO PRZEKŁADU

Brossat, A. (2016). Le Bonheur n'est pas une partie de plaisir. Cabiers critiques de philosopbie, $15,9-22^{2}$.

${ }^{1}$ Alain Brossat (ur. 1946), profesor Uniwersytetu Paris VIII, działacz komunistyczny, autor wielu prac poświęconych idei rewolucji, filozofii politycznej i filozofii współczesnej.

${ }^{2}$ Tekst jest poprawioną wersją wypowiedzi wygłoszonej podczas seminarium René Schérera „Sztuka i życie — obietnica szczęścia”, które miało miejsce 12 lutego 2015 roku w Uniwersytecie Paris VIII. 
W zbiorze artykułów poświęconym Siegfriedowi Kracauerowi (zatytułowanym po francusku: Kracauer l'exilé), amerykański historyk i filozof Martin Jay, specjalista od teorii krytycznej, zauważa: w latach sześćdziesiątych XX wieku Theodor Adorno podejrzewa, że Kracauer, z którym łączy go to, co Jay nazywa „zakłóconą przyjaźnią”, staje się „konformistą dążącym do szczęścia”. Na dowód przytacza w szczególności jego zainteresowanie przemysłem kulturowym jako rzekomą słabość do hollywoodzkiego kina komercyjnego.

To odwrócenie, które ma miejsce w „podejrzeniu” Adorna, zasługuje na szczególną uwagę. Zgodnie z tym poglądem i krytyką nowoczesności, która stanowi jego podstawę, dążenie do szczęścia całkowicie przestaje być horyzontem, w który podmiot etyczny wpisuje swoje zachowania, wręcz przeciwnie, jest ślepym zaułkiem i kapitulacją wobec istniejących warunków - idąc za aforyzmem Adorna, jest okaleczonym życiem. Nie można by było sobie wyobrazić bardziej radykalnego zerwania z nurtem tradycji filozoficznej wywodzącej się ze starożytnej Grecji, skopiowanej przez Rzymian, ponownie podjętej przez Michela de Montaigne'a i innych. W perspektywie „odwróconej”, którą proponuje Adorno, w perspektywie „krytyki”, której broni, zgodność z kosmosem, której szuka podmiot, ten rodzaj harmonii, która stanowi horyzont dążenia do szczęścia, staje się gestem wypaczonym par excellence. Żyć w prawdzie, w duchu krytyki, jest - wręcz przeciwnie — nieustannym kultywowaniem, pogłębianiem niepogodzenia ze światem $\mathrm{w}$ jego obecnej formie, utwierdzeniem się w dysharmonii, a tym samym odrzuceniem wszelkiego rodzaju „szczęścia” rozumianego w ten sposób. Szczęście stało się zepsutym towarem, korupcyjnym uwiedzeniem, ponieważ dąży do pogodzenia podmiotu z kosmosem fałszywym par excellence - światem towarów, światem alienacji podmiotu $\mathrm{z}$ fetyszami lub, używając języka Waltera Benjamina, z fantasmagoriami wszelkiego rodzaju.

Podążając dalej tym tokiem myśli, można powiedzieć, że nie-szczęście, które nie jest tym samym, co nieszczęście, staje się w tej perspektywie oznaką świadomości, autentyczności, czujności. U Adorna podczas jego wygnania w Stanach Zjednoczonych ten stan nie-szczęścia, jako afektywny wymiar krytycznej postawy, przybiera dobrze znaną formę wymiotów na amerykański styl życia, konsumpcjonizm, produkty przemystu kulturowego, formę pogardy dla wszystkich przejawów hedonizmu uprawianego przez „małego człowieka” (John Doe), produkowanych przez amerykańskie społeczeństwo. Przybiera formę tej wielkiej gorzkiej i wyniosłej odrazy, która znajduje ujście w mozaikowych pismach Adorna i Maxa Horkheimera, wydanych przez wydawnictwo Payot w języku francuskim w czerwonej okładce kolekcji kierowanej przez Miguela Abensoura, przybierając ostatecznie kryptoheideggeriańską formę odmowy przez niemieckiego uchodźcę posługiwania się angielskim jako idiomem cywilizowanego barbarzyństwa...

Zamiast rozumnego i niestrudzonego dążenia do szczęścia został wprowadzony, poprzez odwrócenie, bardzo czuły aparat do wykrywania wszystkich 
podłych pokus, aby wywołać złudzenie, że mimo wszystko indywidualny podmiot, człowiek masy, mógłby, jeśli nawet nie znaleźć szczęście, to przynajmniej od czasu do czasu oglądać je z bliska, w taki czy inny sposób, w trakcie swojej egzystencji. Używając wyrażeń Barucha Spinozy i Friedricha Nietzschego, Adorno przechodzi tutaj ze wszystkim, co ma (wplątując w to myślenie krytyczne), do negatywnego afektu myśli i do urazy: odsuną̧ na bok absolutną lub nieodmienną pozytywność dążenia do szczęścia, przybrał postawę wartownika, gliniarza i strażnika, którego misją jest identyfikowanie i potępianie działań oraz podejrzanych zachowań tych, którzy uparcie angażują się w niepewne i same w sobie naganne akcje - pogoń za szczęściem - takie jak na przykład znajdowanie rozrywki w komedii Franka Capry, zainteresowanie westernami Johna Forda, stuchanie utworów be-bopu czy jazzu.

Adorniańskie „podejrzenie” — pojęcie nieodwracalnej kolonizacji/zepsucia idei szczęścia przez świat towarów — stało się powszechne w użyciu w socjologii krytycznej: idea szczęścia jest przesładzana, a nawet rozmyta w zaspokojeniu potrzeb materialnych, komforcie, sukcesie społecznym itp. Szczęście samo w sobie staje się towarem, przedmiotem wymiany, jest sprzedawane, kupowane w jego urzeczowionych formach, ucieleśnione w fetyszach, które otacza szczególna aura: dom z ogrodem w nowej, wystawionej na pokaz dzielnicy rezydencjalnej, fura wypchana gadżetami elektronicznymi i przeznaczona do zabrania całej rodziny na wakacje nad morze, tygodniowy pobyt w luksusowym kompleksie hotelowym pod zwrotnikiem Raka, ślub jak z marzeń zaaranżowany za pośrednictwem płatnego portalu randkowego itd. Ten motyw jest doskonale przetasowany, a jego stereotypowy charakter jest wskaźnikiem pewnego wyczerpania, by nie mówić o zupełnym wyczerpaniu żyły krytycznej według Adorna, ujmując to w skrócie.

Być może mniej istotne jest krytyczne podejście do związku, jaki powstaje dziś między ogólnymi warunkami biopolitycznymi życia podmiotów społecznych a ideą szczęścia lub tym, co z niej pozostaje w obecnym świecie. Kolonizacja tej idei poprzez świat towarów jest drzewem zasłaniającym las: kolonizacją poprzez wiedzę i dziedziny nauki. To, czym się odznacza rozwój nauk społecznych, przemowy naukowe i/lub podające się za naukowe dotyczące człowieka i społeczeństwa od XIX wieku, jest to ściśle mówiąc, charakter zdobywcy i przypuszczenie, implicite lub explicite, według którego podbój przez człowieka nie miałby żadnej granicy, nic nie powinno pozostać poza jego zasięgiem, jeżeli chodzi o wiedzę człowieka i społeczeństwa, nic, co ludzkie, nie powinno pozostać obce, to znaczy odporne na jego procedury dyskursywne. Ten ruch okrążenia lub podboju rozwija się w trybie „nawet i to”, co oznacza kolejne przekraczanie granic oddzielających to, co było zawarte w polu naukowym dyskursu o człowieku i społeczeństwie, od tego, co pozostało na zewnątrz lub poza nim — jest to manifestacja samobójstwa według Emile’a Durkheima: nawet to, co przedstawia się jako osobisty dramat, indywidualna akcja nieobliczalna 
par excellence, nawet to albo raczej to par excellence może i musi być rozważane z punktu widzenia prawidłowości, która przekształca to coś w przedmiot dyskursu naukowego w domenie samej socjologii. Nawet to i przede wszystkim to (według Durkheima taki jest przedmiot socjologicznego odwrócenia odnośnie do samobójstwa) może i musi wejść w wymierne pole.

Ten proces podboju odbywa się na dwóch osiach lub dwóch płaszczyznach: coraz więcej ludzkich celów, zachowań, postaw, wrażliwości, działań itp. wkracza w obszar naukowej dyskursywności i dziedzin, a w konsekwencji nauki ścisłe o człowieku i społeczeństwie rozwijają się w procesach wzrostu i dobrze znanego rozgałęziania geometrycznego: każdego dnia lub prawie każdego dnia pojawia się jakaś nowa nauka lub jej część o ludzkich praktykach i ideach — przestępczości, sporcie, komunikacji, zachowaniach seksualnych, modach, hobby itp. Wystarczy przenieść się z jednego uniwersyteckiego świata do drugiego, z jednego kraju do innego, z jednego kontynentu na drugi, aby odkryć istnienie nieznanych nauk i dyscyplin, które rozwijają się w lokalnych kulturach: na Tajwanie, skąd pochodzę i gdzie zamierzam powrócić, na uniwersytetach, które proponują popularne studia we współpracy z miejscowymi społecznościami aborygenów, można kształcić się w technikach malowania twarzy i napisów na ciele, uczęszczając na poszczególne zajęcia i zaliczając je, jak inni zaliczają zajęcia z Immanuela Kanta lub Michela Foucaulta...

Zauważmy na marginesie, że ten zwycięski duch nauk humanistycznych nie oszczędził nie tylko myśli rewolucyjnej, ale i krytycznego dyskursu najbardziej radykalnego: w latach sześćdziesiątych ubiegłego wieku uwielbialiśmy książkę Wilhelma Reicha, w okresie międzywojennym jednego z ojców tej nowej „nauki”, jaką była wówczas seksuologia, książkę zatytułowaną Funkcja orgazmu, w której jednym z założeń jest to, że przyjemność i mężczyzny, i kobiety jest wymierna. Tak więc ta "miara” jest jednym z kluczowych elementów poznania tej „rzeczy” - przyjemności seksualnej. Przyjemność jako „rzecz” id est przedmiot wymierny - Reich nie oddala się zbytnio od linii wyznaczonej przez Durkheima...

Według tej linii, na tej samej osi, szczęście ma się stać przedmiotem dyskursu i wiedzy na tyle, na ile można je zmierzyć. Jest to to, co nazywam wewnętrznym domniemaniem, co utożsamia się ze „skrzywieniem” nauki o człowieku i nauki o społeczeństwie: chęć produkowania za wszelką cenę wiedzy o wysokim statusie, wiedzy obdarzonej silnym indeksem prawdy („naukowej”) odnośnie do podmiotów nietrwałych, plastycznych, niemogących być zredukowanymi do przedmiotu, takimi jak: przyjemność seksualna, szczęście czy inteligencja. Możemy więc zobaczyć, jak rozwija się w naszych społeczeństwach cały dyskurs miary szczęścia, wpisany w dwupoziomowy horyzont, jeśli mogę tak to ująć - z jednej strony rząd istot żywych i jego warunki, które Foucault nazywa rządomyślnością, a z drugiej zaś sposoby konsumpcji, więź, jaka zachodzi pomiędzy uczuciem szczęścia a konsumpcją. 
$\mathrm{Na}$ pierwszym poziomie założenie proste, ale absolutnie dyskusyjne, polega na tym, że aby można było zarządzać ludźmi, lepiej, by czuli się o ni szczę śliwi, a nie nieszczęśliwi (nie twierdzę, że mają być szczęśliwi, to inna sprawa). Ważne jest więc, aby rządzący wiedzieli (i potrafili zmierzyć), co sprawia, że ludzie czują się szczęśliwi lub nieszczęśliwi, a mówiąc dokładniej, że u ważają się za takich - skoro źródłem wiedzy o szczęściu (lub jego braku) jest prawie zawsze ankieta. W związku z tym zostaną przygotowane kwestionariusze mające na celu zmierzenie poziomu szczęścia odczuwanego przez daną ludność, aby wyciągając wnioski przydatne do zarządzania i na temat zachowania tej ludności.

Przytoczę teraz przykład, wzięty z prasy tajwańskiej (po angielsku): profesor w National Taipei University of Business (ta lokalizacja jest istotna w naszym przykładzie dla tego, co nastąpi) podaje wyniki ankiety, którą przeprowadził, aby, cytuję „zmierzyć poziom szczęścia wśród studentów z Tajwanu”. Podkreśla on, że miara szczęścia w życiu codziennym staje się w ostatnich latach coraz ważniejszym zagadnieniem, ponieważ wyniki tych badań dają wgląd w to, jak ludzie kierują swoim życiem "with an eye toward future success and serenity” (tj. przewidując i ułatwiając ich przyszłe sukcesy i bezpieczne życie). Badacz podkreśla, że to rządy i instytucje są przede wszystkim zainteresowane tymi ćwiczeniami pomiarowymi, aby umożliwić im zdobycie informacji na temat sposobu, w jaki „populacja” (słownictwo biopolityki jako takiej) łączy pewną ideę szczęścia z jej dążeniami do samorealizacji (self-actualisation), sukcesu i poczucia spokoju.

Jego badanie doprowadziło go do stwierdzenia, że poprzez rozszerzenie lub uogólnienie (z jego próbki ankietowanych studentów) wynika, że „Tajwańczycy mają umiarkowany poziom szczęścia” - tłumaczę dosłownie: „The Taiwanese have a 'moderate' level of happiness".

Badanie na pierwszym etapie podkreśla to, co naukowiec określa jako „namacalne” czynniki, które mają być substratem lub warunkami wstępnymi, jeśli nie do szczęśliwego życia, to przynajmniej do dostępu do szczęścia: dobre relacje rodzinne, sieć przyjaciół, dostęp do rekreacji, edukacji, kultury, systemu opieki zdrowotnej — umiarkowana forma rządu (decent governance), swobody religijne - wszystko to w skrócie zapewnia materialne, normatywne, krótko mówiąc cywilizowane podstawy stabilnego, pewnego, znośnego życia. Dzieje się tak oczywiście w społeczeństwie takim jak tajwańskie, zwłaszcza jeśli ktoś zdecyduje się poświęcić ankietę społeczności studenckiej, a nie proletariuszom, którzy ledwie żyją, wykonując różnego rodzaju najgorzej opłacane prace. Ale ten nieco stronniczy wybór nie zapobiega temu, by stan rzeczy później się skomplikował: kiedy okazuje się, że pomimo istnienia dobrze ugruntowanych podstaw stabilnego lub godnego życia studenci, cytuję, nie są bardzo szczęśliwi, a ich wskaźnik lub poziom szczęścia jest znacznie poniżej średniej odnotowanej $\mathrm{w}$ tego typu ankietach na poziomie światowym — do których niedługo dojdę... 
Co dziwne, to w kategorii „wspólnota” zauważono najbardziej widoczny deficyt pod względem elementów lub składników szczęścia, jeśli można tak powiedzieć. W tej dziedzinie „średnie” z wywiadów są 21 do 30 punktów poniżej średniej światowej. Autor ankiety, badacz z Zachodu, podkreśla paradoks takiego wyniku: nie tylko wskazuje na to, że nie ma bezpośredniego związku między istnieniem materialnych, kulturowych i politycznych podstaw życia, czy inaczej mówiąc, między środowiskiem odpornościowym a poziomem „odczuwalnego szczęścia”. Ale również zaskakuje zagranicznego obserwatora, który jest świadomy istnienia w tym kraju kontaktów społecznych nieskończenie bardziej przyjaznych i nieformalnych niż na przykład w kraju takim jak nasz. Zaskakuje on badacza, który zauważa, że studenci w kampusie wydają się stale zanurzeni w różnego rodzaju działaniach zbiorowych, sportowych, kulturalnych, rekreacyjnych, rozrywkowych itp., dysponując wyposażeniem, o którym francuscy studenci mogą tylko pomarzyć...

Ogólnie rzec biorąc, wyniki badania wskazują, jak stwierdza zdziwiony naukowiec, cytuję: "the students are feeling less than overall satisfaction with life”, czyli dosłownie: „studenci odczuwają mniej satysfakcji z ich życia”, innymi słowy, nie są zadowoleni ze swojej osobistej egzystencji. Inaczej mówiąc, wydaje się oczywiste, że z jednej strony tego rodzaju badanie zakończyło się radykalnym niepowodzeniem $\mathrm{w}$ zakresie poinformowania nas, co oznaczałoby dzisiaj szczęście dla młodych ludzi, a jeszcze bardziej dania „jego miary”, z drugiej zaś strony stawia nas ono w obliczu tej potwierdzonej rzeczywistości: dzieci tajwańskiego cudu gospodarczego i stylu życia, który jest z nim związany, w kraju, w którym stopa bezrobocia jest znacznie niższa niż 5\%, a stopa wzrostu gospodarczego na poziomie 5\%, nie są pomimo tego bardziej szczęśliwe. Innymi słowy, jak już trochę przypuszczaliśmy, warunki szczęścia nie wynikają w prostej linii z ogólnych warunków ekonomicznych, są one zależne nie tylko od sposobu i jakości życia, ale bardziej szczegółowo od zagadnienia wspóln ego dobra lub, mówiąc językiem Jeana-Luca Nancy'ego, wzajemnej ekspozycji jednostkowości. Formy serdecznych kontaktów międzyludzkich, sprzyjające jedności i harmonii grupy, regulowane przez niepisane, ale bardzo restrykcyjne konwencje, nie wystarczają do ustalenia warunków, w których osobowości rozkwitają i urzeczywistniają się „szczęśliwie”. Przepaść niemożliwa do wypełnienia pojawia się między komfortem życia a szczęściem osobistym — lub zbiorowym.

Głębia tej przepaści wychodzi na jaw, gdy w dalszym ciągu badania są sugerowane jakieś zalecenia (każde tego rodzaju badanie musi znaleźć swój praktyczny cel). Recepty mające za zadanie połączenie tych dwóch elementów - komfortu życia i szczęścia wykazują niezmiennie niepewność uczących się szczęścia, kuszonych rolą nauczyciela mądrości lub profesora etyki. Wymagają one pozostawania w samotności, bezruchu i ciszy, medytowania przez kilka minut dziennie, ćwiczenia się w okazywaniu współczucia i wdzięczności w swoim życiu oraz wykonywania 
codziennie małych aktów dobroci: a konkretnie, w przypadku studentów, aktywnego uczestniczenia w ochronie i oczyszczaniu środowiska (zaczynając od kampusu). W skrócie, wszystkich rodzajów form oddania się służbie życia zbiorowego, której horyzont nie wykracza poza sposób bycia ułożonych skautów.

$\mathrm{Z}$ braku innych danych przywołane badanie ukazuje, że szczęście jako wartość lub moc czynna jest tym, czego nie można zmierzyć, i jako takie wymyka się kontroli, jaką dyscypliny/wiedza starają się nad nim sprawować. Jest rzeczą osobliwą, że jedyną „rzeczą”, która wydaje się możliwa do zmierzenia, jest brak szczęścia lub niedostatek, czyli enigmatyczna miara nie-szczęścia. Ale wyniki tych badań, więcej niż rozczarowujące, nie zniechęcają do dalszych eksploracji $\mathrm{w}$ innych dziedzinach. Przede wszystkim w tych ankietach, przeprowadzonych, przypominam, na potrzeby marketingu, jak można stwierdzić, ukazuje się podmiot smutny, niezbyt zadowolony ze swojego życia, pozbawiony szczęścia, który z pewnością nie stanowi dobrego konsumenta. W tej perspektywie recepty na szczęście nigdy nie są oderwane od jednoczesnych zachęt do zwiększenia poziomu konsumpcji. W regionie świata, gdzie Benjaminowskie wędrówki zastąpione są zakupami, szczęśliwym człowiekiem jest ten, kto przechadza się po błyszczącym centrum handlowym - człowiek olśniony różnorodnością towarów, z rękoma pełnymi ładnych tekturowych toreb, które same w sobie stanowią nagrodę za dokonane zakupy.

Opowiem wam teraz o Światowym Wskaźniku Szczęścia, po angielsku Happy Planet Index (HPI). Jest to alternatywny wskaźnik ekonomiczny dla produktu krajowego brutto (PKB) i wskaźnika rozwoju społecznego (Human Development Index, HDI) stworzony przez brytyjskie laboratorium pomysłów New Economic Foundation. HPI (w skali od 0 do 100) oblicza się na podstawie trzech wskaźników: wpływu na środowisko, czyli tak zwanego śladu ekologicznego, długości życia i stopnia dobrostanu populacji. Jeśli teraz przejdziemy do uzyskanych wyników, to - najskromniej mówiąc - są zaskakujące. Zgodnie $\mathrm{z}$ najnowszym badaniem (są one przeprowadzane co trzy lata), Namibia i Portugalia odnotowują ten sam wskaźnik HPI: 38,8, mimo że średnia długość życia jest o siedemnaście lat wyższa $\mathrm{w}$ drugim kraju niż w pierwszym $(79,5$ do 62,5$)$. Rozbieżność między ogólnymi warunkami biopolitycznymi a odczuwanym szczęściem wykazana we wcześniej przywoływanych badaniach potwierdza się tutaj w zaskakujący sposób. W sondażu przeprowadzonym w 2006 roku pięć pierwszych krajów pod względem HPI to Vanuatu, Kolumbia, Kostaryka, Dominikana i Panama. W 2009 roku były to Kostaryka, Dominikana, Jamajka, Gwatemala, Wietnam. W 2012 roku Kostaryka, Wietnam, Kolumbia, Belize, Salwador.

W 2006 roku Francja zajmowała 129 miejsce, a Stany Zjednoczone 150 miejsce.

W 2009 roku Francja awansuje na 71 miejsce, a Stany Zjednoczone na 114 miejsce. 
W 2012 roku jest nowy wzrost, Francja zajmuje 50 miejsce, a USA 105 miejsce.

Oto „naukowe” potwierdzenie tego, co każdego dnia postrzegamy jako oczywiste: żyjemy w naszym pięknym kraju coraz bardziej szczęśliwi. Pewnego dnia w końcu dogonimy Salwador.

W tych wynikach uderza brak jakiejkolwiek relacji między istnieniem ogromnych plag lub masowych czynników występującej w jednym z tych społeczeństw a wynikami ankiety: istnieje wysoki poziom przemocy społecznej i politycznej w kraju takim jak Kolumbia, niszczące działanie twardych narkotyków i AIDS w krajach takich jak Jamajka i Dominikana, ślady wyniszczających wojen domowych lub niedawnych ludobójstw w Gwatemali i Salwadorze, istnienie warunków eksploatacji człowieka na pograniczu niewolnictwa w Republice Dominikańskiej (robotnicy pochodzenia haitańskiego wycinający trzcinę cukrową), brak swobód politycznych w Wietnamie, spustoszenia dokonane przez gangi w Salwadorze itp. Innymi słowy, mierzony wskaźnik szczęścia jest niematerialnym wskaźnikiem, całkowicie oderwanym od społecznych, politycznych i historycznych realiów badanych społeczeństw. Można powiedzieć, że to nic więcej jak konstrukcja, produkcja za pomocą odpowiednich środków (wdrożone urządzenie do pomiaru ze zmiennymi danymi) ułudnej rzeczywistości...

Ważne jest, by tutaj zauważyć za Foucaultem, który rozważał konstrukcję wypowiedzi i status wypowiedzi, że gdy wypowiedzi lub elementy narracji świata już są powiedziane, nie tylko zdobywają status wiedzy słusznej, ale i wytwarzają efekty rzeczywistości, wchodząc w skład publicznego dyskursu, zarządzania istotami żywymi, strategii układania wpływu władzy na produkcję wiedzy.

To wytworzone szczęście ma dokładnie tę samą naturę, co opinia sondaży, w której „reprezentatywna próba” respondentów ma ujawnić nam, co Francuzi myślac o karykaturach w Charlie-Hebdo lub miłosnych perypetiach François Hollande'a. Liczą się tutaj niszczycielskie ideologiczne skutki podbojowego imperializmu, jakim jest ta tak zwana wiedza wymierna (subiektywnych podmiotów), za pomocą której specjaliści i inni autoryzowani eksperci przekształcają wytworzone artefakty dyskursywne w niepodważalne fakty.

Krytyka a w zasadzie filozofia, która wciąż traktuje swoją pracę poważnie, jest tutaj upoważniona do potępienia trwałego oszustwa produkcji faktów lub skutków rzeczywistości, której jedynym celem jest zarządzanie ludzkim stadem w najbardziej uwłaczający sposób - zacierając wszelkie różnice między faktem a wierzeniami (Hannah Arendt).

Najbliższy prawdy jest bez wątpienia ten, kto jest najszybszy, kto stwierdzi, że słynny wskaźnik stworzony przez New Economic Foundations nie informuje nas w żadnym stopniu o warunkach szczęścia w naszych społeczeństwach, nie bardziej niż słynne IQ, które rzuca światło na ludzką inteligencję, czy klasyfikacja zaburzeń psychicznych DSM 5 informująca o „poziomie światowego szaleństwa”. Jeśli te mechanizmy pomiaru ludzkich podmiotowości mają nas czegoś 
nauczyć, to przede wszystkim czegoś o ideologii nauki i mniemaniach siejących spustoszenie w dyscyplinach i ośrodkach władzy znajdujących się u źródeł ich powstania. Są to, należy powiedzieć, manufaktury wypowiedzi i osądów, które nic nie znaczą, ale które, właśnie $\mathrm{w}$ tym stanie, mają nieskończoną zdolność infiltrowania i korumpowania osądów opinii publicznej, ponieważ zawsze są wypowiedziami, które mają iluzoryczną „zaletę” prostoty: mieszkańcy Vanuatu są dwa razy bardziej szczęśliwi niż ci w Stanach Zjednoczonych, czarni biegają szybciej niż biali, chłopcy są lepsi w matematyce niż dziewczęta itd.

Jednym ze wskaźników straco nego ostrza dzisiejszej filozofii jest to, że pojawia się ona raczej w poszukiwaniu zjednoczenia z tym, co Foucault nazywa dyscyplinami, naukami społecznymi i humanistycznymi, będąc ostatnim filozofem, który zadaje pytania na temat podstaw ich legitymizacji i pewników, na których opierają się ich imperialne dążenia. Nie można znaleźć nic podobnego (za wyjątkiem błędu i pominięcia z mojej strony) w dziedzinie dzisiejszego filozoficznego dyskursu, co można by było porównać do zjadliwości ataków Foucaulta na kryminologię lub władzę i wiedzę „psychologów” - filozofowie czerpią korzyści z Jacques'a Lacana, Pierre’a Bourdieu, Claude’a Lévi-Straussa i Pierre'a Clastresa. To Michel Onfray, lub jemu podobni, decydują się nagle wrzucić kostkę brukową do kałuży psychoanalizy, robiąc to ze zwinnością niedźwiedzia tak, że kostka spada na nich - tak niezręczna jest to operacja.

Cóż, być może kwestia szczęścia mogłaby być okazją dla filozofii, która wznowiłaby więzi z całym programem archeologii wiedzy a nie z ambicją, by stać się elementem kluczowym całego systemu wiedzy, by przystąpić do ataku - utrzymując twardo, że istnieją przedmioty filozofii, motywy filozoficzne, które, najwyraźniej, pozostają poza zasięgiem prób ograniczenia do warunków, reguł, metody dyscyplin, przytoczonych nauk humanistycznych i społecznych. Durkheim jest bezdyskusyjny, gdy pokazuje, że za dobrowolną śmiercią rozważaną przez filozofa starożytności, kreuje się we współczesnych społeczeństwach obiekt, który pozytywna socjologia z racji swojego przygotowania określa lepiej niż filozofia spirytualistyczna — samobójstwo jako zjawisko społeczne.

Ale szczęście? Najskromniej mówiąc przykłady, o których wspominałem, próby udomowienia lub oswojenia tego potężnego słowa przez profesjonalnych mierniczych ludzkiej subiektywności nie są przekonujące. Można jak najbardziej znaleźć w dziedzinie współczesnych nauk społecznych podejścia mniej niezręczne - cała socjologia krytyczna kolektywnych form hedonizmu wspieranego przez przemysł kulturowy, rekreację, biesiadowanie, seksualne zaspokojenie etc. Czyż viagra, w swoich początkach, nie była sprzedawana jako „pigułka szczęścia”? W związku z tym, że istnieje wiele przemyśleń na temat medykalizacji szczęścia w naszych społeczeństwach z punktu widzenia ogólnej krytyki form biopolitycznych, jest to zadanie, które należałoby raczej do nas, filozofów „foucaultowskich” niż do socjologów. 
Wydaje mi się, że tutaj poruszamy zasadniczą kwestię. To, co my, filozofowie, możemy powiedzieć o szczęściu, ulega zerwaniu w wielu aspektach: jest odcięciem się, jak powiedziałaby Arendt, od starożytnej tradycji (nie wiemy, czym jest „dobre życie”, o którym mówili starożytni, między innymi Arystoteles), a także utratą poczucia tego, co na początku epoki nowoczesnej określaliśmy jako „szczęście publiczne” lub „wspólne” - pojęcia centralnego na przykład w przemowie Maximiliena Robespierre’a i Louisa de Saint-Justa („Szczęście jest nową ideą w Europie!"), ale i rewolucji amerykańskiej. To, że szczęście mogłoby być czymś innym niż pewnym stanem psychicznym - wspólnym uwarunkowaniem politycznym lub państwem kolektywnie zależnym od więzi między ludźmi, to znaczy zagadnieniem odnoszącym się do społe cz ności jest z pewnością czymś, o czym trudno dziś pomyśleć...

Innym podejściem do problemu, które nie mówi nam jednak nic więcej, jest to, o którym przypomina Federico Fellini w Osiem i pót. Do Guida (w tej roli Marcello Mastroianni), który skarży się, że nie znalazł drogi do szczęścia, ubrany na czerwono kardynał mówi sucho, że człowiek nie jest na ziemi, aby być szczęśliwym, ale aby postarać się o swoje zbawienie, co rzadko jest przyjemnością.

Podsumowując, my oraz nam współcześni znosimy generalne osłabienie sensu słowa „szczęście”, które nadużywane do wyświechtania, poniewierane, kojarzone z najbardziej wulgarnymi rzeczami, straciło istotę swojej mocy. W wyniku czego w życiu codziennym jego zastosowanie przeważa w kontekstach błahych, w znaczeniu używanym przez Gianniego Vattima (na przykład gdy babcia mówi „co za szczęście!” o popołudniu spędzonym w towarzystwie swojej wnuczki). W przestrzeni filozofii więcej o szczęściu rozprawiają ci, którzy liczą na szybkie korzyści bez zbędnego wysiłku, niż filozofowie, którzy „drukują”, by posłużyć się językiem dziennikarzy i polityków, ludzi pokroju Andréa Comte-Sponville’a i Michela Onfraya raczej niż myślicieli, którzy się liczą — każdy wpisze sobie tutaj nazwisko, jakie mu przychodzi na myśl... Być może ostatnim „traktatem” o szczęściu, który został opublikowany i który ma bezpośredni związek z wielką tradycją filozoficzną, jest książka, którą Alain publikował w 1911 roku, jego Propos sur le bonbeur. Ale to jest punkt graniczny, punkt krytyczny: Alain jest (szczególnie, to prawda, po pierwszej wojnie światowej) prekursorem filozofa-dziennikarza, który przedstawia siebie jako alternatywa lub uzupełnienie uniwersyteckiego filozofa, który w latach osiemdziesiątych ubiegłego wieku otworzył sklep, by sprzedawać w nim magiczny proszek i inne bezużyteczności.

Nasuwa się zatem pytanie, czy my, filozofowie, otoczeni przez te skutki zerwania czy odrzucenia nadal mamy do powiedzenia coś (co by się liczyło) o szczęściu czy też być może to słowo zniknie z naszego oprogramowania, jak wiele innych słów, które, będąc tak potężnymi w dyskursie filozoficznym, nic już dla nas nie znaczą: opatrzność, ustalona harmonia, istota, przypadek itp. Faktem 
jest, jak już powiedziałem, że nie ma zbyt wielu doktorantów filozofii, którzy zajmują się pisaniem rozpraw naukowych na temat szczęścia - przynajmniej u nas. Jednym z najbardziej oczywistych przejawów zerwania z tradycją jest to, że stoickie podejście do szczęścia - dążenie do stanu umysłu, w którym życiowe doświadczenia i ciosy losu nie podważają naszego spokoju duszy, w którym przykre zdarzenia losowe nie wywierałyby na nas wpływu, gdyż chodzi o coś, czego nie jesteśmy w stanie kontrolować - nie harmonizuje z naszymi subiektywnymi odczuciami najczęściej występującymi: prawie nie wiemy, jak zostawić poza sobą swoje problemy, wszyscy jesteśmy zwolennikami Sartre’a, zanurzonymi w środku walki, nieskończenie „uczuciowymi” z tego tytułu, dotkniętymi tak samo przez sprawy prywatne, wydarzenia intymne, jak i przez wydarzenia na świecie i wszystkie inne zdarzenia z tym związane - popatrzcie na sposób, w jaki zamachy z 7 stycznia 2015 roku wytworzyły, jeśli mogę tak to ująć, w ciągu jednej chwili setki tysięcy przybitych i oburzonych „Jestem Charlie”...

Żyjemy w tym, co niektórzy nazywają wiekiem podatności, i ta słabość, która jest wynikiem naszego wystawienia na świat, na ryzyko, na niebezpieczeństwa rzeczywiste i wyimaginowane, które na nas czyhają, na przeciwności wszelkiego rodzaju, to wszystko zakazuje nam ustanowienia dostosowanego do XXI wieku stoicyzmu, którego jednak jak najbardziej byśmy potrzebowali.

$\mathrm{Z}$ drugiej strony tym, co sprawia, że utknęliśmy w ślepym zaułku z tradycyjną koncepcją szczęścia, a więc że zarówno w tym punkcie, jak i w innych, zerwaliśmy z dziedzictwem, jest nasz stosunek do czasu: według powszechnego rozumienia $\mathrm{w}$ kwestii różnicy między szczęściem a przyjemnością, szczęściem a radością, szczęście, aby zasługiwać na to określenie, musi być stanem umysłu stałym, poddającym się próbie stabilności, podczas gdy przyjemność rozumiana jest raczej jako intensywna, ale krótkotrwała. Odnośnie do radości chcielibyśmy, aby była trwała, jak w tytule Bachowskiego chorału i powieści Jeana Giona - ale nic nie jest w niej trwałe. Teraz okazuje się, że żyjemy w nieskończenie kruchym czasie, podatnym na załamanie, zmianę kierunku, rytmu itp. - czy było to w naszym historycznym stanie, naszym stanie emocjonalnym, moralnym, zawodowym, w naszych gustach, w naszym stylu życia itd.: nie tylko żyjemy w wielu wymiarach czasowych, coraz liczniejszych (od dwudziestu lat Internet dorzuca nam inny wymiar), chodzi przede wszystkim o to, że nasz czas życia może zapaść się w każdej chwili. Ten kruchy czas, który szybko się rozpada, jest wrogiem klasycznej koncepcji szczęścia, tej która z grubsza rzecz biorąc, zachowała się od Epikura do Marzenia samotnego wędrowca Jeana Jacques'a Rousseau. Być może to wyjaśnia rozwój w XX wieku tego, co można nazwać filozofią chwili, a nawet szczęśliwych migawek, filozofią ekstazy u Georgesa Bataille'a, filozofią przyjemności jako punktowego, ale niezapomnianego doznania, którego cechą jest intensywność.

Wszystko wydaje się tutaj odbywać tak, jakby zerwana więź z tradycją mogła być ponownie zawiązana, wbrew wszelkim przeciwnościom, z warunkami 
przerwanego czasu. Pozytywna koncepcja szczęścia, szczęścia dokonania i pokazu siły (w przeciwieństwie do wypełnienia szczęściem charakteryzująca się brakiem bólu), taka aktywna koncepcja szczęścia nie mogłaby, jak się wydaje, rozwinąć się obecnie tylko poza spełnieniem warunku fragmentacji doświadczenia. Szczęście staje się wtedy tym, czego doświadcza się w blasku u ra towanej chwili. Przychodzi nam na myśl książka Jamesa Millera La passion de Foucault, o której mówiliśmy kilka lat temu podczas pamiętnej sesji seminarium René Schérera ze Stéphanem Nadaudem, Davidem Halperinem i kilkoma innymi. Chcę powiedzieć, że można podsumować biografię Foucaulta w tych kilku słowach: całe życie wylewania potu w archiwach i bibliotekach, przerywane niezapomnianymi wyprawami do kalifornijskich darkroomów i innymi przyjemnymi chwilami tego typu. W tej wersji szczęścia nie powiem, że pojawi się, co by się nie działo, jako podejrzany substytut to, co starożytni nazywali szczęściem. Powiem raczej, że biografia Foucaulta pokazuje możliwą i kruchą formę szczęścia dostosowaną do warunków naszej teraźniejszości. Formę Benjaminowską, bowiem jej sposobem ekspresji i manifestacji jest blask. Niekoniecznie formę Proustowską, ponieważ ma ona nie tak wiele wspólnego z pamięcią, jak z intensyfikacją teraźniejszości, mam na myśli moment gorączkowy. Foucault nie cierpiał tych małych rutynowych przyjemności, które mają stworzyć sieć przewidywalnego i rozsądnego szczęścia, opartego na powtarzalności - wypicie z przyjaciółmi dobrej butelki wina, spędzenie wakacji nad morzem, pójście do kina w sobotni wieczór... Chwila ocalona, w której zapisany jest blask szczęścia, powiązana jest z momentem niezwykłym, nieprzewidzianym - czyż Foucault nie twierdził, że najintensywniejszym z tych momentów był dzień, w którym został potrącony przez samochód na ulicy Vaugirard, wychodząc $z$ domu pewnego pięknego letniego popołudnia? Moment ten jest absolutem, niepodzielnym momentem, nie jest nostalgiczny, nie odnosi się do innych ukrytych/straconych scen z przeszłości, sam w sobie jest wystarczający. Ale on jest naprawdę, z drugiej strony, tym, co powracając później we wspomnieniach i stając się opowiadaniem, wzbudzi śmiech radosny i szczery... W tym znaczeniu, wbrew temu, co właśnie dowiodłem, Foucault jest rzeczywiście naśladowcą Prousta — jak my wszyscy.

$Z$ francuskiego przettumaczyt Eukasz ŚWIERCZYŃSKI*

\footnotetext{
* Mgr, nauczyciel języka angielskiego, obecnie student filologii romańskiej w Instytucie Romanistyki Uniwersytetu Pedagogicznego. E-mail: violinpop@gmail.com.
} 